\title{
The Vertical Distribution of Marine Macroplankton. VII. Observations on the Behaviour of Calanus finmarchicus.
}

\author{
By \\ F. S. Russell, D.S.C., B.A., \\ Assistant Naturalist at the Plymouth Laboratory
}

With 6 Figures in the Text.

DuRING the period April to September in 1926 a further series of observations on the vertical distribution of plankton were carried out with the stramin ring-trawl in a manner precisely the same as for those of 1925 , the results of which have already been published (12). The present paper deals only with the results bearing on the behaviour of Calanus finmarchicus (Gunner.)

The collections were made at a position, A, about ten miles from land and two miles west of the Eddystone Lighthouse, in water of a depth of about 54 metres; one only (June 30th) being made at the International Station L4, which lies midway between Rame Head and the Eddystone. On all occasions the Admiralty depth recorder was in use. The full details of the log for all the hauls are not given here, but will be published in a later Report dealing either with the young fish or all the remaining plankton animals collected during the period under observation; the times at which the collections were made are given in Fig. 1, and each haul was of ten minutes' duration.

A sample of 100 Calanus from the catch at each depth was examined for separation into females, males, and young stages, and for making measurements. The total length of the body was measured, i.e. to the end of the caudal furcæ, the furcal setæ being excluded. Under the working conditions the divisions of the micrometer eyepiece corresponded to $0.055 \mathrm{~mm}$. In the case of the males the measurements will not be quite so accurate as those of the females, owing to the habit of many males of dying with the caudal furcæ stretched widely apart; it is doubtful, however, whether this error is of much importance when compared with the differences in total length that occur during the season.

A further source of error may arise when sampling the Calanus, because many males die with their antennæ stretched out away from their bodies, 


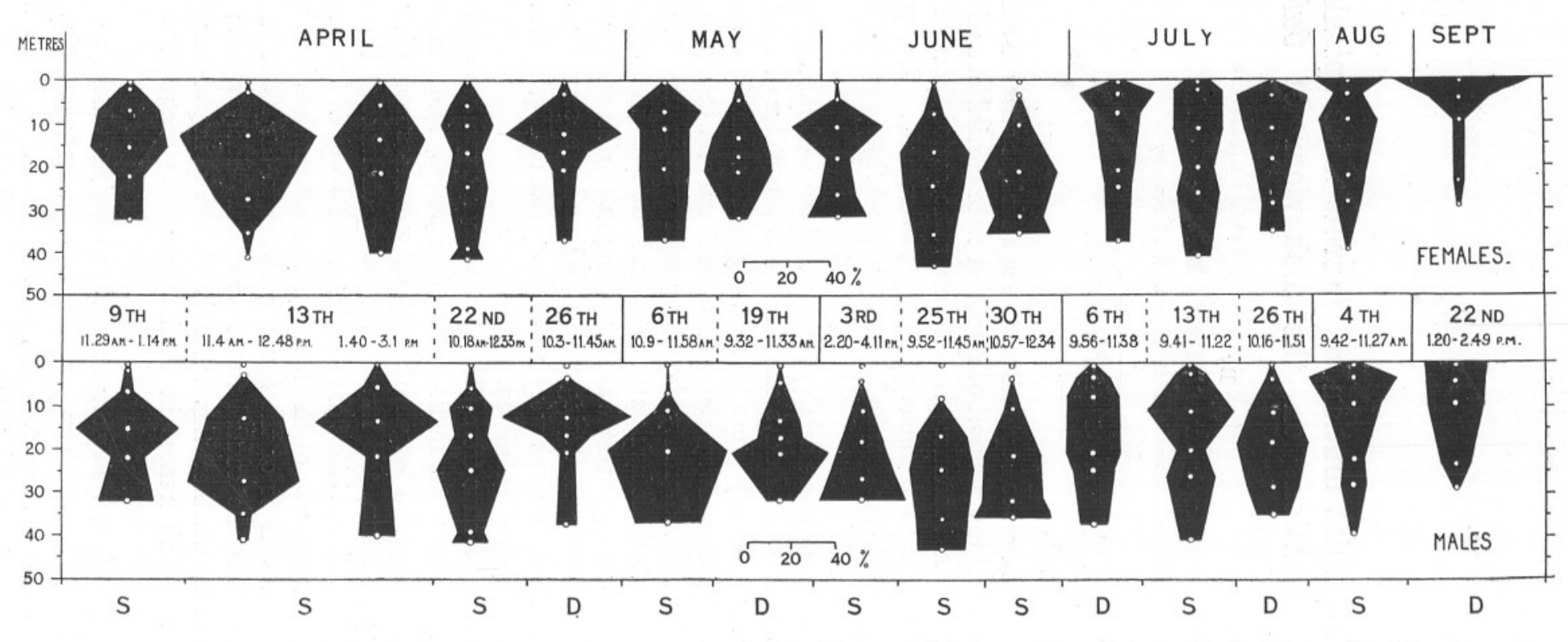

FIG. 1.-The percentage vertical distribution of adult females (top) and males (bottom) of Calanus finmarchicus in the daytime on the dates given, in 1926. The white spots and black circles indicate the average depths at which the hauls were made. The times given are Greenwich Mean Time and denote the time at which the first haul in a series was begun and at which the last haul was finished. $\mathrm{S}=\mathrm{Sunny}$. $\mathrm{D}=\mathrm{Dull}$, 
and unless a very wide-mouthed pipette be used it will be found that females only are sucked up, the males sticking at the entrance. To overcome this difficulty the original collection of the Calanus were well mixed with plenty of water in a small vessel, and successive small samples were poured off and examined until 100 had been measured, whereby almost all the Calanus poured off where examined and there could be no selection by the pipette. By a thorough mixing with plenty of water the tendency for males to cling together by their outstretched antennæ was also prevented.

In Table I, p. 449, are given the total numbers of female and male Calanus in each catch and the average depths at which the collections were made, as shown by the depth recorder. Fig. 1 shows the vertical distribution of the females and of the males on each day, the numbers at each depth being expressed as percentages of the total number taken at all depths on the day in question.

In a previous publication (11) it was shown that there was a tendency for Calanus to move deeper in the water as the season advanced towards the end of June, and that there was a considerable rise towards the surface in July and August. A comparison of Fig. 4 on p. 422 of that publication with the present Fig. 1 shows that there is a striking similarity between the behaviour for the two years. We have once more a gradual descent from the beginning of April to the end of June, and again the very marked rise towards the surface in July and August, with a concentration at the surface in September. Furthermore, there is on certain days, again, a similarity between the actual vertical distribution diagram and the kite-shaped figure which would be theoretically possible if light intensity were the governing factor in controlling the behaviour of the animals (11, Fig. 3, p. 421).

Before proceeding attention must be called to the vertical distribution shown for June 25th in Fig. 1. When this diagram was first drawn it was found that on this day the Calanus were higher in the water than was to be expected under the clear sunny conditions that existed. The reason for this was not apparent until on going over the depth records it was found that on this day, for the only occasion in the season, the recorder was not working satisfactorily; the recording drum was not fully screwed down, so that it had considerable play. Fortunately on the same day samples had been taken at ten different depths with a coarse silk (58 strands to 1 inch) closing net of the dimensions of the international standard net (9). In Fig. 2, A shows the vertical distribution of female Calanus from the ring-trawl collections as first drawn in Fig. 1. C shows the vertical distribution of Calanus females, as shown by catches of the silk closing net. It is clear that they were considerably deeper in the water than the diagram A indicates. 
Accordingly 4 metres was added to each depth of the ring-trawl catches, this being a little less than the full play that was allowed by the recorder drum not being fully screwed down. Fig. 2, B shows the vertical distribution of the Calanus in the ring-trawl collections with these revised depths,

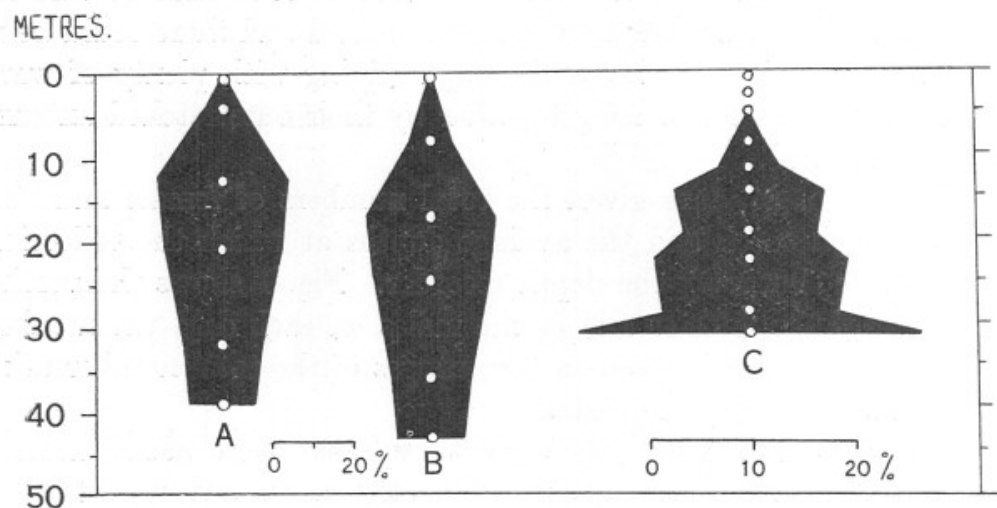

Frg. 2.-A, Vertical distribution of female Calanus caught in ring-trawl on June 25th, 1926, as first drawn in Fig. 1 (see text). B, Vertical distribution of female Calanus caught in ring-trawl on June 25th, 1926, corrected for error due to depth recorder. C, Vertical distribution of female Calanus on June 25th, 1926, as shown by silk closing net collections. The white spots and black circles indicate the average depths at which the hauls were made.

METRES.

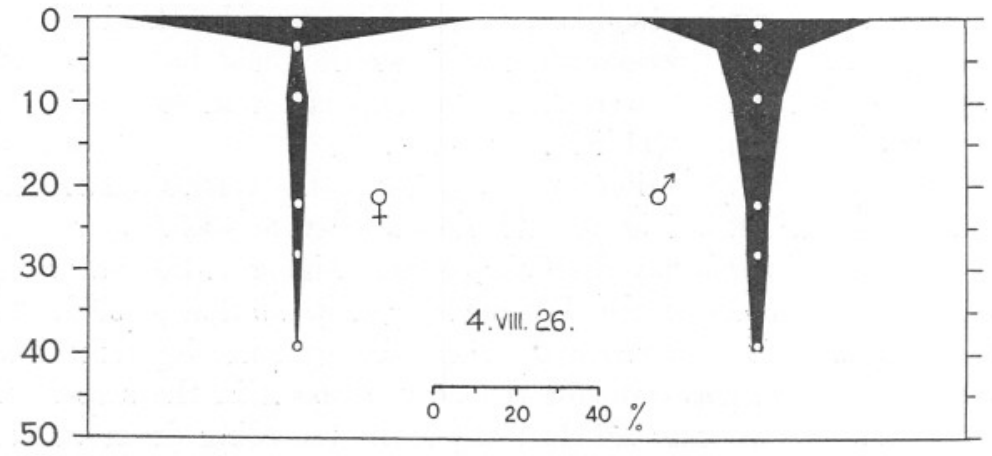

Frg. 3.-Percentage vertical distribution of female and male Calanus on August 4th, 1926, including first surface haul (see text).

and the writer feels that this diagram may be legitimately included, as it has been, in Fig. 1, seeing that it approximates so closely to that as shown by the silk closing net collections in Fig. 2, C.

The diagram in Fig. 1, recording the vertical distribution of Calanus on August 4th, also requires comment. On this day the surface haul 
contained the largest catch of Calanus ever taken during the course of these researches, namely, 175,296 females and 15,936 males. Accordingly, after the full series of collections at the six different depths had been taken a further surface haul was made to see if the Calanus were really more abundant at the surface than in the deeper layers, or whether at that moment we had been steaming through an extraordinarily dense shoal. This second surface haul did not reveal anything like the numbers taken in the first haul, but at the same time it still produced a catch of females greater than at any other depth, showing that the Calanus were undoubtedly much more abundant in the upper layers than deeper down. In Fig. 1, on August 4th, the percentage vertical distribution is drawn, using the numbers from the second and smaller surface haul, as there was no room for the diagram which included the first surface haul. This latter has, however, been reproduced for both females and males in Fig. 3.

\section{Seasonal Changes in the Vertical Distribution of Female Calanus.}

A seasonal change in the vertical distribution of Calanus has been noticed by other workers. Bigelow (2, p. 202) found that the vertical distribution varied somewhat with the season of the year in the Gulf of Maine. In the spring, from February to May, Calanus occurred in all but one of the surface hauls irrespective of the time of day ; while " with the increasing intensity of the sunlight and progressive warming of the water which accompany the advance of the season, the surface stratum evidently becomes less favorable for Calanus, for in summer it is usually decidedly scarce or even wanting in the surface hauls, even at localities where it swarms a few meters down."

Nikitin (8) has also found a seasonal change in the vertical distribution of Calanus in the Black Sea. In a French summary to a paper written in Russian on work carried out from 1923 to 1925 , he says: "Calanus: finmarchicus Gunn. se tient depuis fin novembre jusqu'au commencement de mai $\left(t^{\circ}\right.$ au dessous de $\left.14^{\circ}\right)$ depuis la surface jusqu'à la zone limitrophe (200-175 m.). Les individus jeunes se tiennent de préférence dans les couches supérieures. Vers la fin du printemps, au moment où la $t^{\circ}$ des couches supérieures remonte au dessus de $14^{\circ}, C$. finmarchicus descend vers les couches plus profondes et plus froides ; en été (juin-juillet) il n'apparaît point au dessus de 15 mètres; au mois d'août-au dessus de $25 \mathrm{~m}$. A la fin de l'automne au moment du refroidissement hivernal, il apparaît à nouveau dans les couches superficielles." Nikitin evidently regards temperature as a factor of great importance, and this may well be the case in the Black Sea, where the high average temperature of $24^{\circ}$ is reached in the surface layers. 
It has been mentioned above that the 1926 results (Fig. 1) agree very closely with those for 1925 in showing a gradual descent in the region of maximum abundance from about $10 \mathrm{~m}$. on April 9 th to $20 \mathrm{~m}$. on June 30th, and a marked rise in July, August, and September. In 1925 the sudden rise towards the surface was explained $(11$, p. 427) by the fact that on the days in question the weather was very dull and foggy. An examination of the weather conditions in 1926, however, shows that while on July 6th and 26th and September 22nd the weather was dull, on July 13th and August 4th there was bright sunshine and a cloudless sky. The above explanation can apparently, therefore, no longer hold. On the days on which collections were made observations were taken on the transparency of the water by means of a Secchi's disc $20 \mathrm{~cm}$. in diameter. This was lowered to the depth at which it disappeared, and the results on each day are given in the following table and are plotted graphically in Fig. 4, A (dotted curve).

Secchi Disc Records. 1926.

\begin{tabular}{|c|c|c|c|}
\hline April 9th. & 11.27 a.m. & $10 \mathrm{~m}$ & etres. \\
\hline & 1.25 p.m. & 12 & ", \\
\hline , 13th. & 11 a.m. & 12 & , \\
\hline & 12.55 p.m. & 10 & , \\
\hline & 1.36 p.m. & 9 & , \\
\hline & 3.6 p.m. & 9 & , \\
\hline ,, 22nd. & 10.12 a.m. & 10 & ", \\
\hline & 12.40 p.m. & 11 & ", \\
\hline „, 26th. & 10 a.m. & $11 \cdot 5$ & , \\
\hline & 12.45 p.m. & 13 & , \\
\hline May 6th. & 10.7 a.m. & $9 \cdot 5$ & , \\
\hline & 12.30 p.m. & 9 & , \\
\hline , 19th. & 9.25 a.m. & 13 & , \\
\hline & 12 p.m. & 11 & ", \\
\hline June 3rd. & 4.20 p.m. & 10 & ", \\
\hline , 4th. & 9.20 a.m. & 10 & ", \\
\hline ,, 25th. & 9.50 a.m. & $19 \cdot 5$ & , \\
\hline & 12 p.m. & 20 & , \\
\hline July 6th. & 11.47 a.m. & 14 & , \\
\hline ", 13th. & 11.30 a.m. & 13 & , \\
\hline ,, 26th. & 12 p.m. & $12 *$ & " \\
\hline 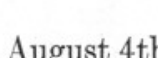 & & $\begin{array}{r}11+ \\
9+\end{array}$ & $"$ \\
\hline
\end{tabular}

* Leeward side.

$\dagger$ Windward side.

$\ddagger$ The same on both sunny windward and shady leeward side. 
On July 15th a series of observations were taken, showing how the transparency varies from place to place.

\begin{tabular}{lcl}
7.30 a.m. & Knap Buoy. & \multicolumn{2}{c}{14 metres. } \\
8 a.m. & L3 & $16.5 \quad$, \\
8.30 a.m. & L4 & $17 \cdot 5 \quad$, \\
9.15 a.m. & L5 & $17 * \quad$, \\
& & $15 \dagger \quad$, \\
10 a.m. & L6 & $12 \quad$, \\
10.35 a.m. & E1 & $12 \quad$, \\
1.30 p.m. & E1 & $13 \quad$, \\
1.55 p.m. & E1 & $13 \quad$, \\
3.40 p.m. & L4 & $15 \ddagger \quad$, \\
& & $15 \cdot 5 \S, "$
\end{tabular}

On the same diagram, Fig. $4, \mathrm{~A}$, is given a curve showing the depths at which the value of $20 \%$ could first be read off from the vertical distribution diagrams for female Calanus in Fig. 1 on each day, thus giving approximately the changes in depth distribution that occurred with the female Calanus from day to day (unbroken curve). It can be seen that the two curves follow one another very closely until the beginning of July. This is only to be expected, seeing that the greater the transparency of the water the greater the light penetration, apart from the fact that the light also increases in intensity after April. But in July and August, although the transparency of the water is once more much as it was in April and May, the Calanus are nevertheless very much closer to the surface.

The possibility suggested itself that the light at the end of the summer might differ somewhat in composition from that in the spring; that perhaps owing to the presence of much moisture in the upper atmosphere from evaporation at the sea surface there was an increased absorption of ultra-violet rays in July and August.

I have to thank Professor Leonard Hill, of the Medical Research Council's Laboratory at Hampstead, for kindly supplying me with figures for the amount of ultra-violet radiation measured at Lyme Regis on the Dorset coast, on the days on which the plankton collections were taken. The readings were as follows :-

Lyme Regis, 1926,

\begin{tabular}{|c|c|c|c|}
\hline April 9th. & 5 & June 25th. & 8 \\
\hline , 13th. & 6 & , 30th. & 12 \\
\hline , $22 \mathrm{nd}$. & 3.5 & July 6th. & $3 \cdot 5$ \\
\hline , 26 th. & 2 & , 13th. & $12 \cdot 5$ \\
\hline May 6th. & $6 \cdot 5$ & , 26th. & 2 \\
\hline , 19th. & 6 & August 4th. & 10 \\
\hline June 3rd. & $9 \cdot 5$ & September 2 & $8 \cdot 5$ \\
\hline $\mathrm{On}=$ & $\begin{array}{l}\text { side. } \\
\text { side. }\end{array}$ & $\begin{array}{l}\dagger \text { On } \\
\S \text { On }\end{array}$ & $\begin{array}{l}\text { side. } \\
\text { side. }\end{array}$ \\
\hline
\end{tabular}




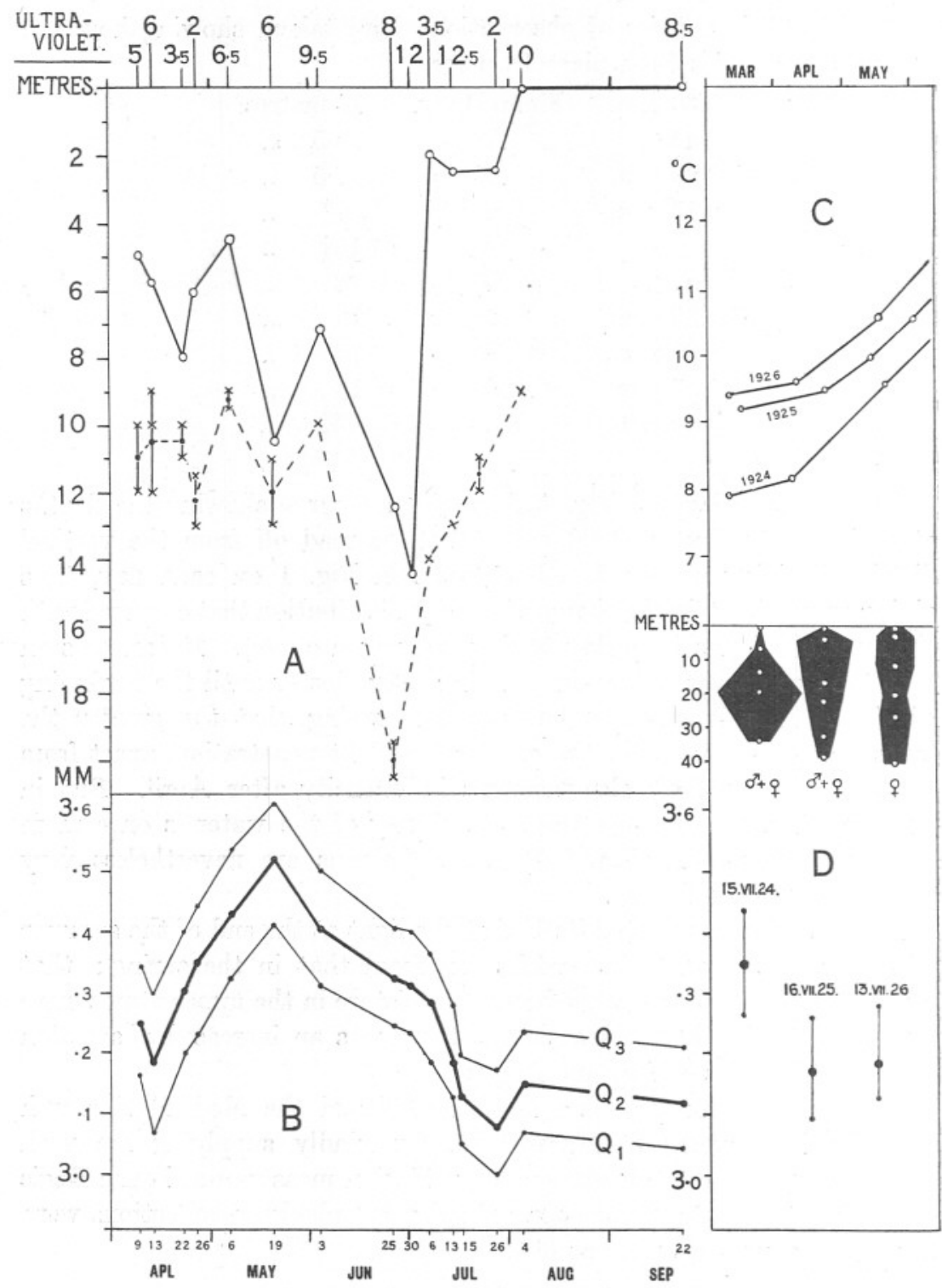

FIG. 4.-At top are given the ultra-violet radiations in 1926 for Lyme Regis on the dates indicated at the bottom of the figure. A, - = curve showing depths at which female Calanus first reached $20 \%$ in abundance below the surface on the dates given ; 1926: $-------=$ depths at which the Sechi dise disappeared from sight. B, Median lengths and upper and lower quartiles in millimetres of female Calanus on the dates given, 1926. C, Curves showing temperatures recorded at 25 metres at the International Station El for March, April, and May in 1924, 1925, and 1926. D, Above are shown the percentage vertical distribution of Calanus on July 15th, 1924, July 16th, 1925, and July 13th, 1926, respectively; below are given the median lengths and upper and lower quartiles for the Calanus on these same dates. 
These readings show a gradual increase in the radiation from April to June 30th, but there is no evidence of any decrease in July and August except on dull days; in fact, the highest record occurs on July 13th. We can therefore say that there is no evidence that the cause of the upward movement of Calanus lies in a decrease of the ultra-violet radiation.

In Table II* (p. 450) are given the measured lengths of female Calanus from all depths sampled on each day, and in Table V (p. 453) are the median lengths and upper and lower quartiles for each day calculated from Table II. (The median here approximates to the average length, and the upper and lower quartiles are the lengths within which $50 \%$ of the samples lie.) These results, $Q_{2}$ the median, and $Q_{3}$ and $Q_{1}$ the upper and lower quartiles, are plotted as a curve in Fig. 4, B. It can at once be seen that there is a marked seasonal change in length, the highest median length, $3.52 \mathrm{~mm}$, , being recorded on May 19th, and the lowest, $3.08 \mathrm{~mm}$., on July 26th. The seasonal change in the size of copepods is a well-known phenomenon, and had already been noted for Calanus by Gran in 1902 (6, p. 60). Recently Adler and Jespersen (1) have studied it for three species of copepods, Pseudocalanus elongatus, Temora longicornis, and Calanus finmarchicus, in the North Sea and Cattegat. They found a regular seasonal change in size for Pseudocalanus and Temora over a period of nearly four years. For Calanus they only had records for a period of one year, and these results show well that this periodic change in size is a phenomenon exhibited by the copepodite stages as well as by the adults. For the adults, however, the numbers sampled were on many occasions very small, and there would therefore be no gain by comparing their measurements with mine.

This phenomenon of change of size with season appears to be closely related with the seasonal temperature changes (Fig. 5). The Calanus born in the early spring when the sea temperature is low give rise to a brood of large adults; these large adults probably spawn intermittently throughout the months of May and June when the temperature of the water is rising rapidly. Their offspring form a brood of small individuals making their appearance as adults in late June and early July, and predominating from then onwards. Although I have no winter observations the indications are that this summer brood of small individuals probably reproduce late in the summer when the temperature is still fairly high and give rise to a brood of small individuals, some of which tide over the winter months to form the original stock for the spring breeding

* In these and following tables data are given for 4 series on June 3rd-4th and 1 at El on July 15th, but the vertical distribution of Calanus on these occasions will not be dealt with in this paper. 
in the following year. It can be seen from the curve that early in April the Calanus were small.

It is a striking fact that when the brood of small adults begins to predominate in the collections early in July the change appears in the behaviour of the Calanus and they move nearer the surface. The suggestion at once presents itself that this summer brood may be physiologically different from the brood of large individuals which precedes them in the spring. While the brood of large Calanus prefer a somewhat low intensity of light and live deep in the water, gradually going deeper as the strength

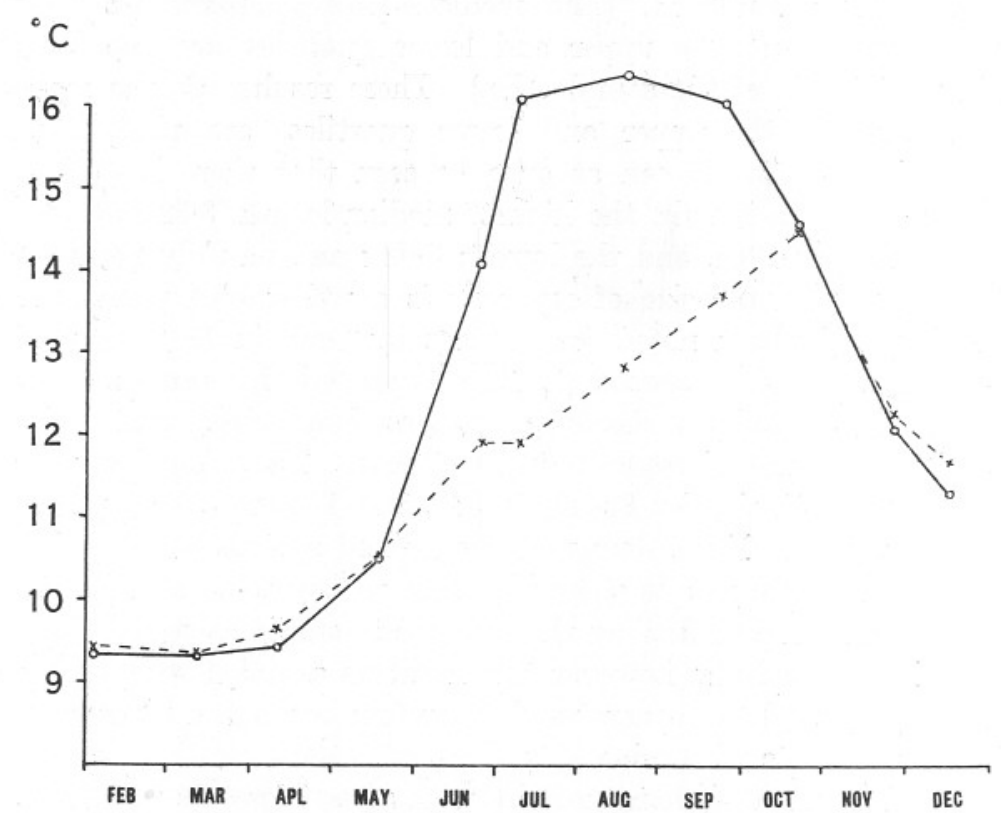

FIG. 5.-Temperatures at International Stations L5 (surface), continuous line, and El (25 metres), broken line, in 1926.

of light increases with the season, the "small" summer brood perhaps prefers a higher intensity of light and lives considerably nearer the surface.

This suggestion receives support from a totally unexpected direction. In Fig. 4, D, are given the vertical distribution diagrams for Calanus on the 15th, 16th, and 13th of July in 1924, 1925, and 1926, respectively. It will be noticed that while in 1925 and 1926 the Calanus were high up in the water and close to the surface, in 1924 they were much deeper in the water, having their region of maximum abundance at 20 metres. But if the sizes of the Calanus on these three days be examined it will be found that while the 1925 and 1926 Calanus do not differ appreciably, 
the 1924 specimens were very much larger. The medians, and lower and upper quartiles on each day, are given in Fig. 4, D, below the vertical distribution diagrams to which they refer, and the figure shows clearly the difference in size between the 1924 Calanus and the 1925 and 1926 specimens. Also on comparing these with Fig. 4, B, we see that while the 1925 and 1926 Calanus lie within the size range of the small summer brood, those of 1924 lie well outside this range and tend towards the average size of the large spring individuals.

The actual data are given below; the 1924 and 1925 measurements include both males and females, but the 1926 are only females. This will not, however, upset the general result, because males are always slightly smaller than females and the tendency would be to make the 1924 measurements smaller if anything than they should be.

\begin{tabular}{|c|c|c|c|}
\hline Mm. & $\begin{array}{c}\text { June 15th, } \\
1924 . \\
q+0\end{array}$ & $\begin{array}{c}\text { July 16th, } \\
1925 . \\
++\delta\end{array}$ & $\begin{array}{c}\text { July 13th, } \\
1926 . \\
+\end{array}$ \\
\hline $2 \cdot 86$ & - & - & 1 \\
\hline $2 \cdot 915$ & - & 6 & 5 \\
\hline $2 \cdot 97$ & - & 8 & 11 \\
\hline $3 \cdot 025$ & 4 & 20 & 14 \\
\hline $3 \cdot 08$ & 2 & 20 & 21 \\
\hline $3 \cdot 135$ & 4 & 22 & 53 \\
\hline $3 \cdot 19$ & 9 & 24 & 27 \\
\hline $3 \cdot 245$ & 14 & 15 & 29 \\
\hline $3 \cdot 3$ & 17 & 18 & 24 \\
\hline $3 \cdot 355$ & 15 & 4 & 9 \\
\hline $3 \cdot 41$ & 15 & 1 & 5 \\
\hline $3 \cdot 465$ & 9 & - & 1 \\
\hline $3 \cdot 52$ & \& & - & - \\
\hline 3.575 & 2 & - & - \\
\hline $3 \cdot 63$ & 1 & - & - \\
\hline $3 \cdot 685$ & 1 & - & - \\
\hline $\mathrm{Q}_{1}$ & $3 \cdot 264$ & $3 \cdot 082$ & $3 \cdot 12$ \\
\hline $\mathrm{Q}_{2}$ & $3 \cdot 348$ & $3 \cdot 174$ & $3 \cdot 18$ \\
\hline $\mathrm{Q}_{3}$ & $3 \cdot 435$ & $3 \cdot 260$ & $3 \cdot 27$ \\
\hline
\end{tabular}

In Fig. 4, C, are given the temperature curves of the sea in March, April, and May in the three years 1924, 1925, and 1926. It shows that for March and April the temperature was fully a degree lower in 1924 than in the other two years, and in May it was half a degree lower than in 1925 and a whole degree lower than in 1926. 
The temperatures at 25 metres at the International Station El were as follows :-

1924.

1925.

1926 .

Feb. 15th. $8 \cdot 70^{\circ} \mathrm{C}$. Feb. 17th. $10 \cdot 01^{\circ} \mathrm{C}$. Feb. 3rd. $9 \cdot 40^{\circ} \mathrm{C}$.

Mar. 10th. $7 \cdot 90^{\circ} \quad$ Mar. 14th. 9.18 $\quad$ Mar. 11th. $9 \cdot 37^{\circ}$

April 8th. $8 \cdot 15^{\circ} \quad$ April 22nd. 9.44 ${ }^{\circ}$ April 10th. 9.65

May 20th. $9 \cdot 59^{\circ} \quad$ May 13th. $9 \cdot 96^{\circ} \quad$ May 17th. $10 \cdot 55^{\circ}$

June 17th. $10 \cdot 49^{\circ} \quad$ June 3rd. $10 \cdot 55^{\circ} \quad$ June 24th. 11.92

July 9th. $11 \cdot 54^{\circ} \quad$ July 8th. $11 \cdot 85^{\circ}$ July 8th. $11 \cdot 90^{\circ}$

Aug. 7th. $12 \cdot 01^{\circ} \quad$ Aug. 5th. $12 \cdot 02^{\circ} \quad$ Aug. 16th. $12 \cdot 86^{\circ}$

Sept. 3rd. $12 \cdot 34^{\circ}$

Sept. 22 nd. $13 \cdot 76^{\circ}$

The large size of the Calanus in July, 1924, may have been caused by the low temperature at which they were born, and it is easily conceivable that physiologically they would approach more nearly in their reactions and behaviour to the brood of large individuals which predominated in the spring in 1926 than to the brood of small Calanus which followed later. This would perhaps explain why in 1924 the Calanus were much deeper in the water in the daytime in mid-July than in either of the two years 1925 and 1926.

The above suggestion of physiologically different broods appearing during the year might be tested in another way. Fig. 4, B, shows that in the spring the size of the Calanus increases gradually until a maximum size is reached in May, it then decreases gradually until by July the small size becomes more or less stable with only slight variations. The most obvious explanation is that the gradual increase in size is due to a mixture of small and large individuals, i.e. the small adults of the previous summer's brood now spawning and the large adults resulting from this spawning. The proportion of large to small increases gradually, the small dying off, and more and more large reaching maturity, until at the peak of the curve the population consists almost homogeneously of large individuals. The gradual downward slope of the curve until July can be explained in a similar but reverse manner, the large ones dying off until the small summer adults predominate.

If such were the case we should expect that on May 19th the population consisted homogeneously of Calanus of the brood of large individuals, and from July onwards to early April of the "small" brood. But at the periods between early April and May 19th and the latter date and July the populations would not be homogeneous, but would consist of mixtures of "large" and "small" individuals. If these two types of broods truly differ in their reactions towards external conditions a comparison of depth distribution with size might show a tendency for a segregation of the smaller individuals to the upper layers and the larger 
individuals to the deeper layers at those times when the population was mixed, a differentiation which should not be apparent when the populations are homogeneously "large " or " small." Owing to the wide range of size of both the "large" and the "small " types it is impossible to show whether a population is homogeneous or not by size measurements alone, since the two ranges overlap to such an extent as to form a unimodal curve which may be truly unimodal or consist of the addition of two little-separated modes on a bimodal curve.

Unfortunately the numbers of females measured at each depth on any single day are not sufficiently great to allow any calculations to be made. I have attempted to arrive at a solution by grouping several days together. For instance, one might group together all the days from July 13th to September 22nd inclusive. during which period the population should be homogeneously "small," and one could take together April 22nd and 26th and May 6th, when the population may be a mixture of "large " and " small " broods. But while in the former case the method may be fairly legitimate, in the latter the results would be severely vitiated by the fact that there is a relatively enormous difference in average size between the individuals from day to day. No evidence of any difference in size with depth could be found from July 13th onwards, but a very slight tendency for the large forms to congregate in the deeper layers was shown for April 22nd and 26th and May 6th. No such tendency, however, was shown on June 25th and 30th and July 6th, when one expects the population to have become once more heterogeneous. On the whole, the data do not warrant such minute examination, and we must await the time when a large number of measurements can be made on any single day. It might be remarked that with a homogeneous population, although the actual range of size is large, calculation of a number of days lumped together (July 13th to September 22nd) showed no evidence of changes in size with depth. This, perhaps, is to be expected, seeing that all were presumably born under the same conditions and have reached the same stage of development. Segregation by size is shown by many plankton animals, notably Sagitta, but it must be remembered that with Sagitta size is a criterion of age rather than of development, corresponding actually to the various growth stages of a moulting crustacean, and segregation by growth stages has been shown for Calanus.

Although some evidence has been put forward to support the suggestion made above that the summer and spring broods of Calanus are physiologically different, we must not lose sight of the fact that so little is as yet known of the actual seasonal changes in light conditions beneath the sea surface that we cannot say that this apparent seasonal change in the behaviour and reactions of Calanus is not due entirely to changes in external conditions and not to any physiological differences at all. 


\section{Seasonal Changes in Vertical Distribution of Male Calanus.}

Fig. 1 shows that the males differ in their behaviour from the females, being always slightly deeper in the water than the latter. This is shown clearly in Fig. 6, A, in which are plotted the depths below the surface

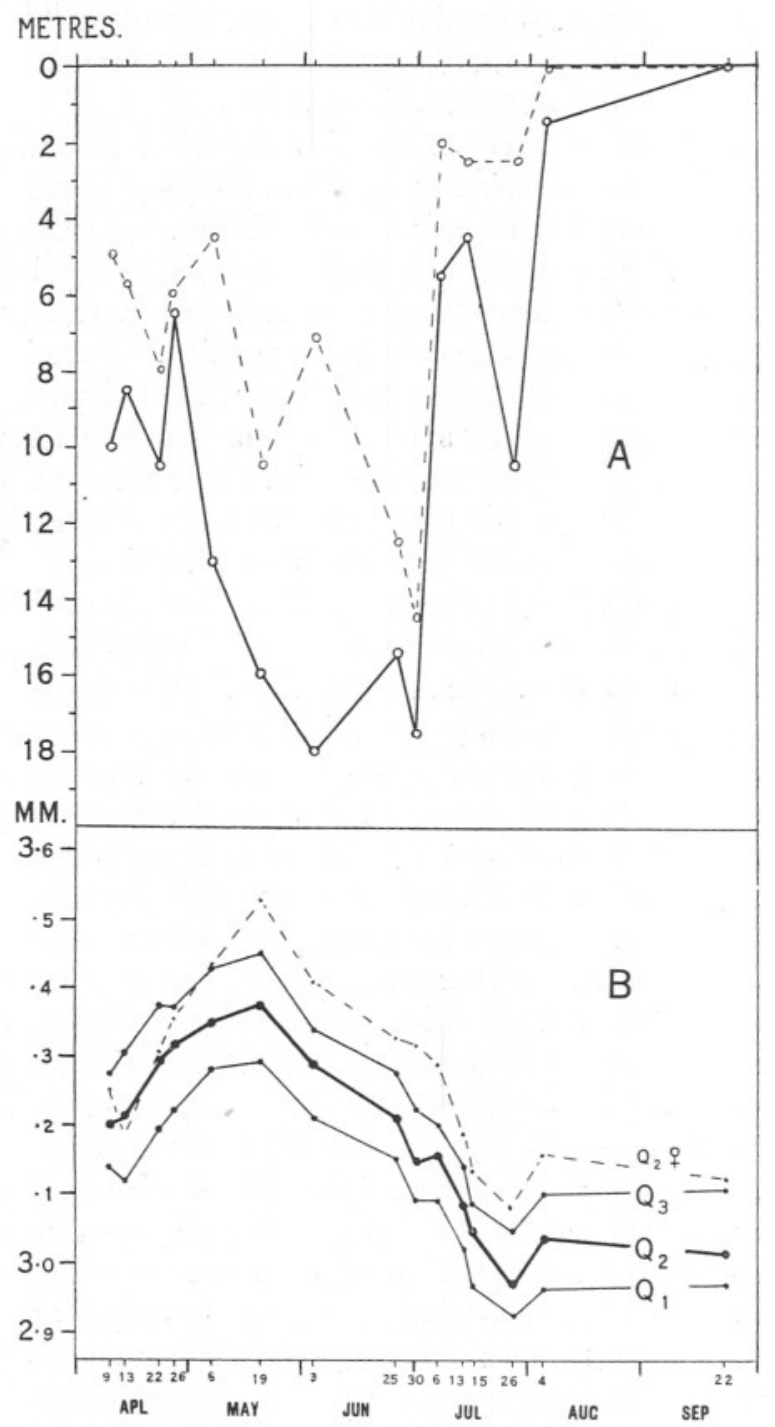

FIG. 6.-A, - $=$ depths at which male Calanus first reached $20 \%$ in abundance ; $-----=$ ditto for females. B, Median lengths and upper and lower quartiles in millimetres for male Calanus on the dates given; - - - - - = median lengths for females. 
at which the male Calanus first reach $20 \%$ in abundance on each day. For comparison the similar curve for the female Calanus has been reproduced from Fig. 4, and is shown as a dotted curve in Fig. 6, A. Indications of this difference in behavour between Calanus males and females have already been noticed by other workers (Paulsen, 10, p. 16).

Fig. 6, B, shows the measured lengths of the male Calanus as shown for the females, viz. the median and upper and lower quartiles. For comparison the median for the females is shown as a dotted curve. It can be seen that in essentials the males show a similar seasonal change in size to that of the females, the only difference being that the males were always slightly smaller than the females, except early in April when they were about the same size. Full details of the measurements of the males are to be found in Tables III and V. The highest and lowest median lengths of the males were $3.37 \mathrm{~mm}$. on May 19th and $3.01 \mathrm{~mm}$. on September 22nd as opposed to $3.52 \mathrm{~mm}$. for the females on May 19th and $3.08 \mathrm{~mm}$. on July $26 \mathrm{th}$. It is to be noticed that while the females approach very nearly to the smallest limits of the males, the males never reach anything like the largest sizes of the females.

\section{The Presence of Swarms of Calanus at the Surface.}

It has been hard to reconcile the fact that the sun's light is the main factor in causing Calanus to avoid the surface layers in the summer with the occasional occurrence of vast swarms of this copepod at the surface itself. The results of this present research appear, however, to afford an explanation.

During my observations I have never yet met with Calanus in great abundance in the surface layers in the daytime after April except in the months of July, August, and September. In the following extract from a work by H. B. Bigelow, who finds indications of a seasonal change in the vertical distribution of Calanus in the Gulf of Maine (2, p. 203), it can be seen that July and August are again the only months mentioned in which swarming at the surface in sunlight occurred: "I have already pointed out that its absence on the surface in the regions where it swarms in deeper water is not caused altogether by sunlight, for while it probably does tend to descend during the most brilliantly illuminated hours, on several occasions we have made rich catches on the surface when the sun was high in the sky. Such was the case off the entrance to Gloucester harbor on July 22, 1912 (Station 10012), when nearly a litre was taken in the 4-foot net on the surface at about 3 p.m. Again, on August 14, 1914 (Station 10251), we made a rich surface catch of Calanus at about 2 p.m. off Cape Elizabeth; in July, 1916, a month when C. finmarchicus was notably abundant, surface hauls yielded considerable numbers off Cape 
Cod at 4 p.m. (Station 10345), and off Martha's Vineyard at 5 p.m. (Station 10351). Willey (13, p. 181) records the "presence en masse of $C$. finmarchicus at the surface between 3 and 4 p.m. under a bright sun." This occurred on September 14th, but there was a possibility that this may have been a forced swarming caused by hydrographical conditions, since Dr. A. G. Huntsman observed a stirring up of the water by tidal currents.

If it is a general rule that these swarms are only met with on the surface in the months of July, August, and September, and not in May and June, their presence ceases to contradict the light intensity theory, for all my observations so far point to the conclusion that it is the rule and not the exception for Calanus to be high up in the water in these months.

\section{On the Life-History of Calanus in the Plymouth Area.}

A certain amount of information on the life-history of Calanus in this region is given by the measurements and calculations in Tables II, III, and $\mathrm{V}$ and Figs. 4, B, and $5, \mathrm{~B}$.

Crawshay (Lebour, $\mathbf{7}$ ) has shown that the complete development of Calanus from egg to the last copepodid stage (V) may be passed through in the Laboratory within two months. At this rate then it appears probable that the brood of large individuals which is beginning to predominate at the end of April may have developed from eggs hatched early in March. The brood of small adults appearing in June, July, and August must have arisen from this brood of large individuals. Table II shows that practically all the females of a size less than $3 \cdot 1 \mathrm{~mm}$. had disappeared from the catches by the middle of May, presumably having died off. Any adults of this small size that appear in the catches two months after this date must therefore be the offspring of the brood of large individuals prevailing in May. Seeing that we have direct evidence that all the Calanus below a size of $3 \cdot 1 \mathrm{~mm}$. have died off, it is quite reasonable to presume that the whole brood of small adults predominating early in April has died off by the middle of May, and that the July brood is an entirely new brood arising from the spawning of the large individuals which predominate in the middle of May.

Furthermore, by the end of June almost all the adult females of a size greater than $3.5 \mathrm{~mm}$. had disappeared from the catches. If this means that they have died off, as it surely must do, it indicates that their length of life cannot have exceeded much more than three months, presuming that they were the offspring of the small adults which spawned in March. If, again, all those above $3.5 \mathrm{~mm}$. have died off it seems probable that the whole of this brood of large individuals may have died by July.

At the same time it seems very probable that the small adults present in the summer will spawn intermittently throughout the months of July 
and August, and perhaps September, giving rise to a brood, some of which will tide over the winter months to spawn early in the following spring, and produce once more a brood of large individuals.

Schematically this will give us :-

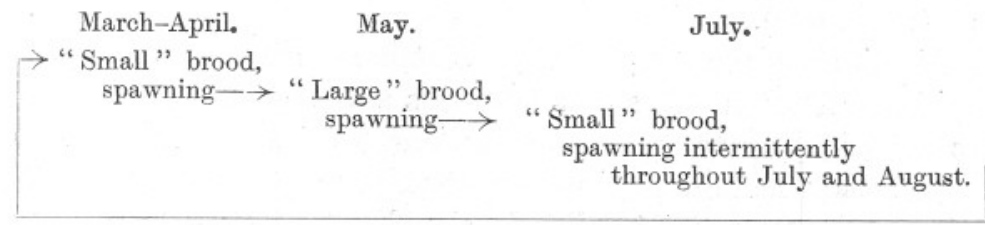

An examination of the numbers of females carrying spermatophores shows that the percentage was always very low during the months under observation. The following table, which shows the percentages, at all depths combined, on each day indicates that there is a slight increase in the middle of April, which soon falls off and is followed by a similar increase towards the end of July and beginning of August.

$\begin{array}{crccr} & & \% & & \% \\ \text { April 9th. } & \cdot 6 & \text { June 3rd. } & \cdot 7 \\ \text {, 13th(i). } & 1 \cdot 5 & \text { " 25th. } & 1 \cdot 2 \\ \text {, 13th(ii). } & 3 \cdot 5 & \text { July 6th. } & 0 \cdot 0 \\ \text {, 22nd. } & 3 \cdot 4 & \text { " 13th. } & 1 \cdot 4 \\ \text {, 26th. } & \cdot 5 & \text { ", 26th. } & 2 \cdot 6 \\ \text { May 6th. } & \cdot 4 & \text { August 4th. } & 3 \cdot 3 \\ \text {, 19th. } & \cdot 9 & \text { September 22nd. } 0 \cdot 0\end{array}$

Farran (4, p. 85) records the presence of females bearing spermatophores on the south coast of Ireland in February, May, and August.

This outline of the life-history of Calanus in this region agrees in essential with that given recently by Farran (5) for the south coast of Ireland deduced from the abundance of the different stages of development. He says: "In April there is a sudden outburst of reproduction, of which indications have already appeared in March, but then on such a small scale as not to cause any appreciable increase in stock. . . Reproduction goes on irregularly all through the summer. . . . The adults of the previous year probably do not live beyond April or May, their places being taken by specimens hatched earlier in the year, which have rapidly gone through their metamorphoses." 


\section{On the Occurrence of the Last Copepodid Stage (Stage V) in the Ring-Trawl Catches.}

In a previous publication I stated that " a catch of Calanus finmarchicus made by the stramin ring-trawl consists nearly always of over $80 \%$ adults" (12, p. 605).

In Table VI are given the percentage abundance of females, males, and Stage $\mathrm{V}$ in each catch. It shows that this statement held good for 51 catches out of 59 up to and including June 30th, and on three of the eight occasions, when Stage $\mathrm{V}$ were present to the extent of more than $20 \%$, the numbers were too small to be significant. But in the remaining catches, from July 6th to September 22 nd, out of 30 there were 20 in which Stage V occurred as more than $20 \%$ of the catch, even reaching $60 \%$ and $70 \%$ in August and September. This probably indicates that in these latter months the Stage V Calanus were actually so very much more abundant than the adults that even those that were retained in the net outweighed the number of adults caught. Farran (5, p. 141) says for the south coast of Ireland that in September "the majority of specimens are now definitely in Stage V."

Owing to the obvious fact that the stramin ring-trawl cannot be regarded as an efficient instrument for the capture of these last copepodid stages, because it probably allows many to pass through the meshes, I have not attempted to express diagrammatically their vertical distribution. The actual numbers caught are, however, given in Table VII.

Although we do not know to what extent the full range of size of the Stage $\mathrm{V}$ are sampled, the measurements of total lengths and the calculations of median and upper and lower quartiles based on them given in Tables IV and V are of interest. They show the seasonal change in size in the same manner as do the adults. From the small length of $2 \cdot 76 \mathrm{~mm}$. on April 22nd the median rises to a maximum of $3.04 \mathrm{~mm}$. on May 19th, falling again to a minimum of $2.69 \mathrm{~mm}$. on July 29th. This shows that the increase in the numbers of Stage V in the July, August, and September catches cannot be put down to an increase in size.

\section{SUMMARY.}

1. The vertical distribution of Calanus finmarchicus adults in the daylight in the Plymouth region as shown by stramin ring-trawl catches is described for the period April to September in 1926. The general results confirmed the indications given in $1925^{*}$ that there is a gradual descent of the region of maximum abundance from about 10 metres in April to

* In the summary to the paper recording these results $(12$, p. 605$)$ there is a misprint-1926 should read 1925 . 
20 metres in June, with a definite rise towards the surface in July, August, and September.

2 . The rise towards the surface was evident on sunny days as well as dull, indicating that the suggestion that dull weather and low light intensity was its cause in 1925 may possibly have been incorrect.

3. Measurements of the total lengths of Calanus were made which showed a seasonal change, a brood of small adults occurring in July, August, and September, as opposed to a brood of large adults which dominated in the spring.

4. It is suggested that possibly these two broods are physiologically different, and that the small type of adult prefers a higher light intensity and lives nearer the surface than the large type.

5. The males and females differed in their behaviour, the males being always slightly deeper in the water than the females.

6. Some indications are given of the course of the life-cycles of Calanus in the Plymouth area.

7. While from April to the end of June the abundance of the last copepodid stage (Stage V) rarely exceeded more than $20 \%$ of the total Calanus in any one catch, they became very much more abundant in July, August, and September, reaching even $60 \%$ and $70 \%$.

\section{REFERENCES.}

1. Adler, G., and Jespersen, P. Variations saisonnières chez quelques Copépodes planctonique marins. Meddel. fra Komm. for Havunders. Serie : Plankton. Bd. II. 1920.

2. Bigelow, H. B. Plankton of the Offshore Waters of the Gulf of Maine. Bull. Bur. Fish. Washington. Vol. XL. 1924. Part II. Document No. 968. 1926.

3. Damas, D. Notes Biologiques sur les Copépodes de la Mer Norvégienne. Conseil Internat. pour l'Explor. de la Mer. Publ. de Circ., No. 22. 1905.

4. Farran, G. P. Copepoda. Conseil Internat. pour l'Explor. de la Mer. Bull. Trimestr., Deux Part. 1911.

5. Farran, G. P. The Reproduction of Calanus finmarchicus off the South Coast of Ireland. Conseil Internat. pour l'Explor. de la Mer. Journ. du Conseil., Vol. II, No. 2. 1927.

6. Gran, H. H. Das Plankton des Norwegischen Nordmeeres. Rep. Norweg. Fish. Mar. Invest., Vol. II, Pt. II. 1909. No. 5. (1902.) 
7. Lebour, M. V. Stages in the Life-History of Calanus finmarchicus (Gunnerus), Experimentally Reared by Mr. L. R. Crawshay in the Plymouth Laboratory. Journ. Mar. Biol. Assoc., N.S., Vol. XI. 1916-18.

8. Nikitin, V. La distribution verticale du plancton dans la mer Noire. I. Copepoda et Cladocera. Acad. Sci. Républ. Soviét Social. Ser. II, No. 9. Travaux du laboratoire zoologique et de la station biologique de Sebastopol, p. 93. 1926.

9. Ostenfeld, C. H., And Jespersen, P. Standard Net for Plankton Collections. Conseil Internat. pour l'Explor. de la Mer. Publ. de Circ., No. 84. 1924.

10. Paulsen, 0. Studies on Biology of Calanus finmarchicus. Medd. fra Komm. Havunders., Plankton, Bd. I, No. 4. 1906.

11. Russell, F. S. The Vertical Distribution of Marine Macroplankton. IV. The Apparent Importance of Light Intensity as a Controlling Factor in the Behaviour of Certain Species in the Plymouth Area. Journ. Mar. Biol. Assoc., N.S., Vol. XIV, No. 2, p. 415. 1926.

12. Russell, F. S. The Vertical Distribution of Marine Macroplankton. V. The Distribution of Animals Caught in the Ring-trawl in the Daytime in the Plymouth Area. Journ. Mar. Biol. Assoc., N.S., Vol. XIV, No. 3, p. 557. 1927.

13. Wrlley, A. Report on the Copepoda obtained in the Gulf of St. Lawrence and adjacent waters, 1915. Canadian Fisheries Expedition, 1914-1915, p. 173.1919. 
TABLE I.

Average Depths of each Haul $(D)$ in Metres and Numbers of Calanus Females and Males in each Catch.

\begin{tabular}{|c|c|c|c|c|c|c|c|c|c|c|c|c|c|c|c|c|}
\hline & \multicolumn{3}{|c|}{ April 9th. } & \multicolumn{3}{|c|}{ April 13th (i.) } & \multicolumn{3}{|c|}{ April 13th (ii.) } & \multicolumn{3}{|c|}{ April 22nd. } & \multicolumn{3}{|c|}{ April 26th. } & \\
\hline & $D$ & 우 & o & $D$ & 우 & o & $D$ & 우 & ta & $D$ & 우 & o & $D$ & & o & \\
\hline & $S$. & 60 & 5 & $S$ & 1 & - & $S$. & 13 & 2 & $S$. & 211 & - & $S$. & 144 & 14 & \\
\hline & 2 & 812 & 31 & $2 \cdot 8$ & 70 & - & $5 \cdot 8$ & 431 & 43 & $5 \cdot 9$ & 1,527 & 74 & $3 \cdot 2$ & 589 & 23 & \\
\hline & 7 & 2,456 & 55 & 13 & 2,175 & 140 & $13 \cdot 8$ & 916 & 181 & $10 \cdot 4$ & 2,198 & 345 & $12 \cdot 6$ & 5,088 & $1, \overline{6} 96$ & \\
\hline & $15 \cdot 5$ & 2,738 & 438 & $27 \cdot 6$ & 1,115 & 207 & $21 \cdot 6$ & 561 & 34 & $16 \cdot 9$ & 1,245 & 266 & $16 \cdot 7$ & 1,885 & 649 & 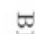 \\
\hline & $22 \cdot 4$ & 958 & 146 & $35 \cdot 4$ & 316 & 30 & $40 \cdot 1$ & 213 & 61 & $24 \cdot 6$ & 1,798 & 534 & $20 \cdot 8$ & 1,030 & 200 & 떤 \\
\hline & $32 \cdot 4$ & 1,047 & 225 & 41 & 175 & 18 & - & - & - & 39 & 829 & 215 & $37 \cdot 1$ & 738 & 258 & 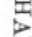 \\
\hline & & & & & & & & & & $41 \cdot 3$ & 1,390 & 290 & - & - & - & $\leq$ \\
\hline \multirow[t]{8}{*}{ Totals. } & & 8,071 & 900 & & 3,852 & 395 & - & 2,134 & 321 & - & 9,198 & 1,724 & - & 9,474 & 2,840 & 엉 \\
\hline & \multicolumn{3}{|c|}{ May 6 th. } & \multicolumn{3}{|c|}{ May 19th. } & \multicolumn{3}{|c|}{ June 3rd. } & \multicolumn{3}{|c|}{ June 25th. } & \multicolumn{3}{|c|}{ June 30 th. } & $e_{x}^{2}$ \\
\hline & $\underset{G}{D}$ & ${ }^{+}{ }_{3}$ & 0 & $D$ & 우 & o & $D$ & 우. & $\hat{\sigma}$ & $D^{*}$ & 우 & o & $D$ & 우 & o & $?$ \\
\hline & $\begin{array}{c}S . \\
7.3\end{array}$ & $\begin{array}{r}3 \\
4.897\end{array}$ & $=$ & $S$. & - & - & $S$. & 117 & 6 & $S$. & 5 & - & $S$. & 20 & - & 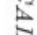 \\
\hline & $\begin{array}{r}7 \cdot 3 \\
11 \cdot 2\end{array}$ & $\begin{array}{l}4,897 \\
3.245\end{array}$ & 59 & $4 \cdot 6$ & 1,032 & 323 & $4 \cdot 3$ & 2,000 & 43 & $8 \cdot 2$ & 1,113 & 12 & $3 \cdot 5$ & 10 & 10 & \\
\hline & $\begin{array}{l}11 \cdot 2 \\
20 \cdot 4\end{array}$ & $\begin{array}{l}3,245 \\
3964\end{array}$ & 299 & $13 \cdot 4$ & 4,382 & 1,587 & $10 \cdot 8$ & 40,437 & 3,145 & $16 \cdot 9$ & 3,607 & 1,219 & $10 \cdot 4$ & 909 & 493 & \\
\hline & $\begin{array}{l}20 \cdot 4 \\
37 \cdot 1\end{array}$ & $\begin{array}{l}3,264 \\
2,656\end{array}$ & 1,360 & $17 \cdot 6$ & 5,306 & 1,842 & 18 & 10,876 & 6,296 & $24 \cdot 6$ & 2,776 & 1,607 & $21 \cdot 4$ & 2,759 & 1,549 & w \\
\hline & & $\begin{array}{c}2,656 \\
-\end{array}$ & $\begin{array}{c}747 \\
-\end{array}$ & $\begin{array}{r}21 \cdot 1 \\
32\end{array}$ & $\begin{array}{l}5,545 \\
1,601\end{array}$ & $\begin{array}{l}3,824 \\
104\end{array}$ & $\begin{array}{l}26 \cdot 6 \\
31.5\end{array}$ & $\begin{array}{l}16,585 \\
26,441\end{array}$ & 10,120 & 36 & 2,227 & 1,306 & $31 \cdot 6$ & 1,760 & 1,654 & \\
\hline \multirow[t]{11}{*}{ Totals. } & & 14,065 & 2,465 & - & 17,866 & 8,680 & - & 96,456 & 32,201 & $\begin{array}{c}40.1 \\
-\end{array}$ & $\begin{array}{r}1,901 \\
11.629\end{array}$ & $\begin{array}{l}1,162 \\
5,306\end{array}$ & $35 \cdot 2$ & 2,332 & 2,047 & \\
\hline & & - & & & & & & 80,700 & & & $11,0<9$ & 0,300 & - & 7,790 & 6,703 & \\
\hline & \multicolumn{3}{|c|}{ July 6th. } & \multicolumn{3}{|c|}{ July 13th. } & \multicolumn{3}{|c|}{ July 26 th. } & \multicolumn{3}{|c|}{ Aug. 4th. } & \multirow{2}{*}{\multicolumn{3}{|c|}{ Sept. 22nd. }} & \\
\hline & $D$ & 8 & 0 & $\therefore D$ & 웅 & o & $D$ & q & $\sigma^{+}$ & $D$ & o & 0 & $D$ & & & \\
\hline & $S$. & 235 & 78 & $S$. & 270 & - & $S$. & 20 & - & $\int S(i)$. & 175,296 & 15,936 & $s$. & 3,317 & 121 & in \\
\hline & $3 \cdot 3$ & 2,781 & 876 & $2 \cdot 3$ & 572 & 260 & 3.9 & 756 & 85 & $S($ ii. $)$ & 11,679 & 916 & $4 \cdot 4$ & 1,467 & 116 & \\
\hline & $7 \cdot 9$ & 1,698 & 1,455 & $11 \cdot 2$ & 584 & 701 & $11 \cdot 5$ & 614 & 307 & $3 \cdot 5$ & $.4,895$ & 5,402 & $9 \cdot 6$ & 254 & 109 & \\
\hline & 20.9 & 1,190 & 1,459 & $20 \cdot 1$ & 377 & 234 & 18.5 & 428 & 469 & $9 \cdot 5$ & 9,590 & 3,563 & $23 \cdot 5$ & 250 & 58 & \\
\hline & $24 \cdot 7$ & 1,084 & 1,112 & $26 \cdot 4$ & 509 & 403 & $28 \cdot 7$ & 223 & 347 & $22 \cdot 2$ & 5,641 & 1,410 & $28 \cdot 7$ & 106 & 20 & \\
\hline & $37 \cdot 2$ & 874 & 713 & $40 \cdot 7$ & 302 & 190 & $35 \cdot 1$ & 264 & 216 & $28 \cdot 2$ & 4,362 & 1,670 & - & - & - & \\
\hline & & & & & & & & & & $39 \cdot 4$ & 640 & 461 & - & - & - & \\
\hline Totals. & & 7,862 & 5,693 & - & 2,614 & 1,788 & - & 2,305 & 1,424 & - & $\overline{-}$ & - & - & 5,394 & 424 & \\
\hline & & & & & & & & & & & $\begin{array}{r}200,424 \\
\text { or } 36,807\end{array}$ & $\begin{array}{l}28,442 \\
13,422\end{array}$ & & & & \\
\hline
\end{tabular}

* Depth corrected for error due to depth recorder (see text, p. 431). 
TABLE II.

Measurements of Total Length of Female Calanus in Millimetres.

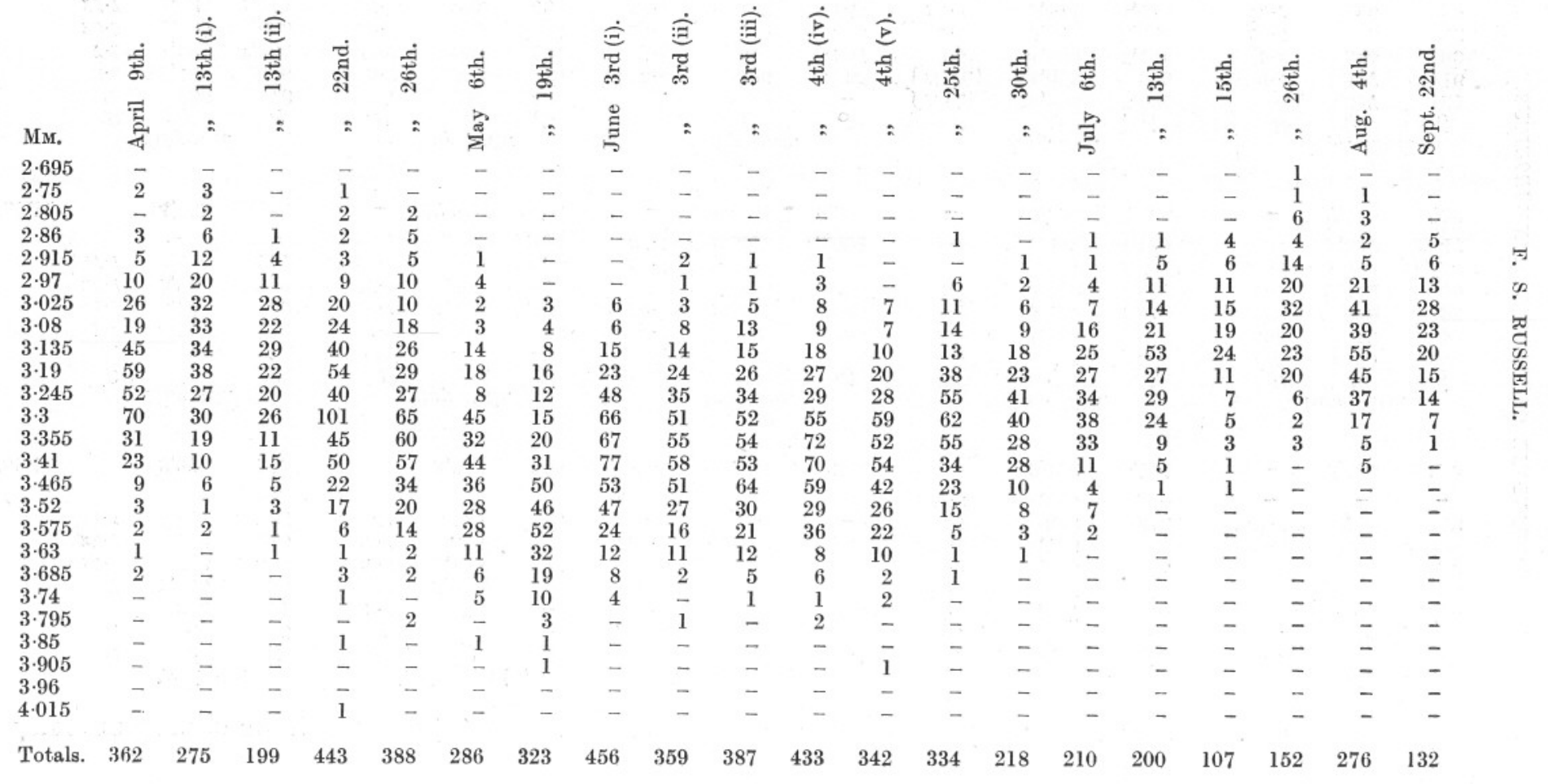


TABLE III.

Measurements of Total Length of Male Calanus in Millimetres.

\begin{tabular}{|c|c|c|c|c|c|c|c|c|c|c|c|c|c|c|c|c|c|c|c|c|}
\hline & 㤐 & 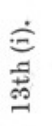 & 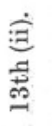 & 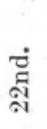 & 击 & ક્ષี & 苟 & & $\underset{\dot{\Xi}}{\dot{\Xi}}$ & 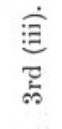 & 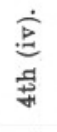 & 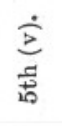 & 苦 & 䒿 & की & 琣 & 突 & 葛 & 㱏 & ఫี่ \\
\hline Мм. & 竞 & $=$ & $=$ & $=$ & $=$ & $\stackrel{\text { }}{2}$ & $\therefore$ & $\stackrel{\Xi}{\Xi}$ & $=$ & $=$ & : & $=$ & $=$ & $=$ & $\stackrel{\infty}{\Xi}$ & $=$ & 2 & $=$ & $\dot{\vec{z}}$ & 苟 \\
\hline $2 \cdot 75$ & - & - & - & - & - & - & - & - & - & - & - & - & - & - & - & 1 & - & 3 & - & - \\
\hline $\begin{array}{l}2 \cdot 805 \\
2 \cdot 86\end{array}$ & - & - & - & - & - & - & - & - & - & - & - & - & - & - & - & - & - & 7 & 1 & - \\
\hline $\begin{array}{l}2 \cdot 86 \\
2 \cdot 915\end{array}$ & $=$ & - & - & 3 & - & - & - & - & - & - & - & - & - & 2 & 1 & 6 & 2 & 6 & 5 & $\bar{z}$ \\
\hline $\begin{array}{l}2 \cdot 915 \\
2 \cdot 97\end{array}$ & $\overline{-}$ & - & - & 2 & - & - & 1 & $\overline{-}$ & 2 & 4 & 1 & - & 3 & 2 & $\begin{array}{l}4 \\
9\end{array}$ & 9 & 3 & 23 & 23 & 5 \\
\hline 3.025 & $\overrightarrow{2}$ & $\overrightarrow{4}$ & $\begin{array}{l}3 \\
3\end{array}$ & $\begin{array}{l}2 \\
4\end{array}$ & $\begin{array}{l}1 \\
3\end{array}$ & $\overline{-}$ & $\begin{array}{l}1 \\
1\end{array}$ & $\begin{array}{l}1 \\
3\end{array}$ & $\overline{1}$ & $\begin{array}{l}1 \\
4\end{array}$ & $\begin{array}{l}1 \\
3\end{array}$ & $\overline{3}$ & $\begin{array}{l}4 \\
7\end{array}$ & $\begin{array}{l}13 \\
17\end{array}$ & $\begin{array}{r}9 \\
18\end{array}$ & $\begin{array}{l}18 \\
30\end{array}$ & $\frac{2}{7}$ & $\begin{array}{l}14 \\
13\end{array}$ & $\begin{array}{l}18 \\
22\end{array}$ & $\begin{array}{l}6 \\
2\end{array}$ \\
\hline 3.08 & 8 & 4 & 2 & 2 & 6 & 2 & 4 & 9 & 4 & 6 & 8 & 7 & 10 & 27 & 30 & 31 & 3 & 8 & 22 & 3 \\
\hline $3 \cdot 135$ & 9 & 4 & 2 & 7 & 5 & 3 & 4 & 8 & 13 & 24 & 13 & 23 & 27 & 36 & 37 & 21 & 1 & 2 & 7 & 2 \\
\hline $3 \cdot 19$ & 13 & 4 & 4 & 10 & 11 & 4 & 10 & 22 & 28 & 20 & 22 & 23 & 31 & 33 & 34 & 9 & - & - & 2 & - \\
\hline $3 \cdot 245$ & 5 & 4 & 6 & 12 & 7 & 6 & 20 & 18 & 40 & 23 & 14 & 29 & 20 & 12 & 12 & 2 & - & - & - & - \\
\hline $3 \cdot 3$ & 2 & 3 & 4 & 16 & 28 & 12 & 24 & 21 & 34 & 26 & 17 & 41 & 15 & 11 & 6 & 1 & - & - & - & - \\
\hline $3 \cdot 355$ & 3 & 1 & 2 & 9 & 8 & 10 & 33 & 15 & 17 & 14 & 25 & 12 & 4 & 1 & 1 & - & - & - & - & - \\
\hline $3 \cdot 41$ & - & 2 & 1 & 12 & 6 & 8 & 23 & 9 & 11 & 8 & 10 & 8 & 1 & - & - & - & - & - & - & - \\
\hline 3.465 & - & - & 1 & 1 & 5 & 1 & 18 & 4 & 2 & 4 & 4 & 4 & - & - & - & - & - & - & - & - \\
\hline 3.52 & - & - & - & - & 1 & 2 & 5 & 2 & 1 & - & 3 & $\overline{1}$ & - & - & - & - & - & - & - & - \\
\hline $\begin{array}{l}3 \cdot 575 \\
3 \cdot 63\end{array}$ & - & - & - & 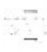 & $\begin{array}{l}1 \\
1\end{array}$ & 3 & $\begin{array}{l}6 \\
1\end{array}$ & $\overline{1}$ & - & - & - & $\begin{array}{l}1 \\
-\end{array}$ & - & - & - & - & - & $\overline{-}$ & - & - \\
\hline Total, & 42 & 26 & 28 & 80 & 83 & 51 & 151 & 113 & 153 & 134 & 121 & 151 & 122 & 154 & 152 & 128 & 18 & 76 & 100 & 18 \\
\hline
\end{tabular}


TABLE IV.

Measurements of Total Length of Calanus Copepodid Stage V.

\begin{tabular}{|c|c|c|c|c|c|c|c|c|c|c|c|c|c|c|c|c|c|c|c|c|}
\hline & 㤩 & 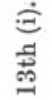 & 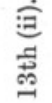 & สี่ & 䓪 & تే & 苛 & 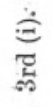 & $\begin{array}{l}\dot{\hat{\Xi}} \\
\text { 己. }\end{array}$ & 总 & $\begin{array}{l}\dot{\vec{E}} \\
\underset{f}{+}\end{array}$ & $\begin{array}{l}\dot{\vec{D}} \\
\text { 毒 }\end{array}$ & 营 & 萢 & 苗 & 蛋 & 蕌 & تُ & 亲 & ีำ \\
\hline Мм. & 鸹 & $=$ & $\therefore$ & $=$ & $=$ & $\stackrel{d}{2}$ & $=$ & $\stackrel{\Xi}{\Xi}$ & $=$ & $=$ & $=$ & $=$ & $=$ & $=$ & $\stackrel{B}{\Xi}$ & $\therefore$ & : & $\Rightarrow$ & 递 & 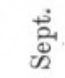 \\
\hline $2 \cdot 31$ & - & - & - & - & - & - & - & - & - & - & - & - & - & - & - & - & - & - & 1 & - \\
\hline $\begin{array}{l}2.365 \\
2.49\end{array}$ & - & 1 & - & - & - & - & - & - & - & - & - & - & - & - & - & - & 1 & - & - & 1 \\
\hline $\begin{array}{l}2 \cdot 42 \\
0.475\end{array}$ & $\overline{3}$ & 1 & - & - & - & $=$ & - & - & - & 1 & - & - & - & - & - & - & 1 & 1 & 4 & 5 \\
\hline $2 \cdot 475$ & 3 & 1 & 3 & 1 & 1 & - & - & - & - & - & - & - & 1 & - & 3 & 2 & 3 & 5 & 3 & 13 \\
\hline $2 \cdot 53$ & - & 3 & 1 & - & 1 & $=$ & - & 1 & - & 1 & - & - & 3 & - & 4 & - & 1 & 4 & 10 & 11 \\
\hline $2 \cdot 585$ & 5 & 5 & 6 & 2 & - & - & - & - & 2 & - & 1 & 1 & - & - & 6 & 2 & 3 & 12 & 25 & 21 \\
\hline $2 \cdot 64$ & 2 & 3 & 4 & 6 & 1 & 1 & 1 & - & 4 & 1 & 2 & - & 3 & 1 & 8 & 2 & 2 & 15 & 34 & 25 \\
\hline $2 \cdot 695$ & 7 & 7 & 5 & 7 & - & 1 & 1 & 1 & 5 & 1 & 2 & 1 & 5 & 1 & 20 & 9 & 11 & 13 & 41 & 25 \\
\hline $2 \cdot 75$ & 9 & 4 & 13 & 11 & 8 & 10 & 3 & i & 8 & 6 & 8 & 2 & 8 & 2 & 24 & 11 & 8 & 13 & 81 & 53 \\
\hline $2 \cdot 805$ & 2 & 6 & 5 & 9 & 11 & 5 & 1 & 1 & 7 & 8 & 4 & 1 & 9 & 4 & 25 & 15 & - & 5 & 59 & 30 \\
\hline $2 \cdot 86$ & 17 & 2 & 6 & 7 & 17 & 7 & 1 & 4 & 10 & 15 & 3 & 8 & 5 & 11 & 36 & 3 & 5 & 2 & 55 & 23 \\
\hline 2.915 & 9 & 6 & 15 & 20 & 15 & 10 & 1 & 11 & 17 & 15 & 10 & 4 & 6 & 7 & 17 & - & - & 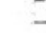 & 19 & 14 \\
\hline $2 \cdot 97$ & 4 & 2 & 1 & 12 & 16 & 7 & 3 & 2 & 12 & $\begin{array}{l}10 \\
22\end{array}$ & 8 & 7 & 2 & 4 & 12 & - & . & - & $\begin{array}{r}10 \\
2\end{array}$ & $\begin{array}{c}14 \\
2\end{array}$ \\
\hline 3.025 & 2 & I & 3 & 12 & 29 & 10 & 7 & 5 & 17 & 4 & 5 & 5 & 2 & 1 & 1 & - & - & - & - & $=$ \\
\hline 08 & 1 & 1 & - & 8 & 22 & 9 & 3 & 2 & 6 & 3 & 1 & 2 & - & - & - & - & - & - & - & - \\
\hline $3 \cdot 135$ & - & - & - & 3 & 13 & 5 & 1 & 1 & - & 2 & - & - & .- & - & - & - & - & - & - & - \\
\hline $3 \cdot 19$ & - & - & - & - & 3 & 5 & - & - & - & - & - & - & - & - & - & - & - & - & - & - \\
\hline $3 \cdot 245$ & - & - & - & - & 1 & 2 & 2 & - & - & - & - & - & - & - & - & - & - & - & - & - \\
\hline $3 \cdot 30$ & - & - & - & - & 1 & - & - & - & - & - & - & - & - & - & - & - & - & - & - & - \\
\hline otal. & 61 & 43 & 62 & 98 & 139 & 72 & 24 & 29 & 88 & 79 & 45 & 31 & 44 & 31 & 156 & 44 & 35 & 70 & 334 & 223 \\
\hline
\end{tabular}




\section{TABLE V.}

Lengths of Female, Male, and Stage V Calanus in Millimetres as Mrdian $\left(Q_{2}\right)$, and $\operatorname{Upper}\left(Q_{3}\right)$ and Lower $\left(Q_{1}\right)$ Quartiles.

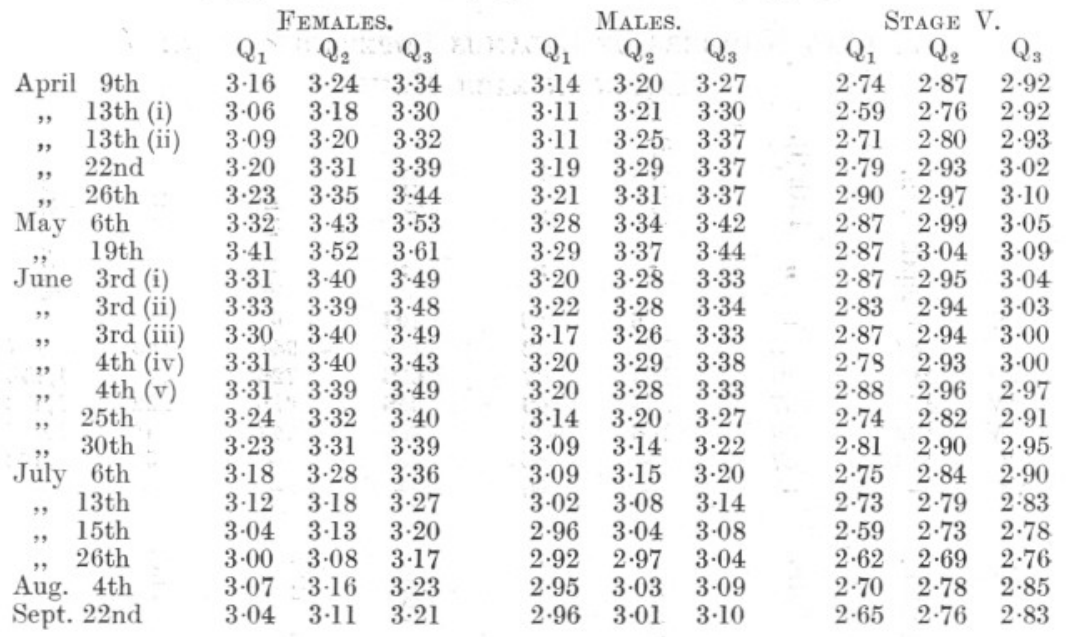

\section{TABLE VI.}

Percentages of Females, Males, and Stage V Calanus in each Catch.

\begin{tabular}{|c|c|c|c|c|c|c|c|c|c|c|c|c|c|c|c|c|}
\hline & & 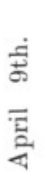 & 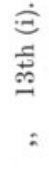 & 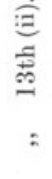 & $\begin{array}{l}\dot{\Xi} \\
\text { aี }\end{array}$ & 莡 & $\begin{array}{l}\text { 苛 } \\
\text { 吾 }\end{array}$ & $\begin{array}{l}\frac{\dot{d}}{\sigma} \\
\therefore\end{array}$ & 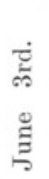 & $\frac{\dot{d}}{10}$ & 突 & 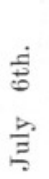 & 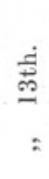 & $\begin{array}{l}\text { 通 } \\
:\end{array}$ & $\overbrace{}^{\stackrel{\dot{j}}{\vec{j}}}$ & 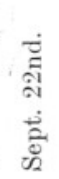 \\
\hline Surface & $\begin{array}{l}q \\
0 \\
\hat{V}\end{array}$ & $\begin{array}{r}92 \\
8 \\
-\end{array}$ & $\begin{array}{r}100 \\
- \\
-\end{array}$ & $\begin{array}{r}62 \\
9 \\
29\end{array}$ & $\begin{array}{r}88 \\
12\end{array}$ & $\begin{array}{r}41 \\
4 \\
55\end{array}$ & $\begin{array}{r}33 \\
- \\
66\end{array}$ & $\begin{array}{l}- \\
-\end{array}$ & $\begin{array}{r}95 \\
5 \\
-\end{array}$ & $\begin{array}{r}50 \\
- \\
50\end{array}$ & $\begin{array}{r}100 \\
- \\
-\end{array}$ & $\begin{array}{l}48 \\
16 \\
36\end{array}$ & $\begin{array}{r}100 \\
- \\
-\end{array}$ & $\begin{array}{r}100 \\
- \\
-\end{array}$ & $\begin{array}{rr}44 & 51 \\
4 & 4 \\
52 & 45\end{array}$ & $\begin{array}{r}55 \\
2 \\
43\end{array}$ \\
\hline II & $\begin{array}{l}\text { q } \\
\text { ô. } \\
\mathrm{V}\end{array}$ & $\begin{array}{r}91 \\
4 \\
5\end{array}$ & $\begin{array}{r}94 \\
6 \\
-\end{array}$ & $\begin{array}{r}70 \\
7 \\
23\end{array}$ & $\begin{array}{r}83 \\
4 \\
13\end{array}$ & $\begin{array}{r}77 \\
3 \\
20\end{array}$ & $\begin{array}{r}83 \\
1 \\
16\end{array}$ & $\begin{array}{l}67 \\
21 \\
12\end{array}$ & $\begin{array}{r}93 \\
2 \\
5\end{array}$ & $\begin{array}{r}92 \\
1 \\
7\end{array}$ & $\begin{array}{r}50 \\
50 \\
-\end{array}$ & $\begin{array}{l}54 \\
17 \\
29\end{array}$ & $\begin{array}{l}55 \\
25 \\
19\end{array}$ & $\begin{array}{r}62 \\
7 \\
31\end{array}$ & $\begin{array}{l}29 \\
32 \\
39\end{array}$ & 59 \\
\hline III & $\begin{array}{l}\text { q } \\
\hat{\rho} \\
\mathrm{V}\end{array}$ & $\begin{array}{r}89 \\
2 \\
9\end{array}$ & $\begin{array}{r}77 \\
6 \\
17\end{array}$ & $\begin{array}{l}71 \\
14 \\
15\end{array}$ & $\begin{array}{l}70 \\
11 \\
19\end{array}$ & $\begin{array}{l}60 \\
20 \\
20\end{array}$ & $\begin{array}{r}76 \\
7 \\
17\end{array}$ & $\begin{array}{r}69 \\
25 \\
6\end{array}$ & $\begin{array}{r}90 \\
7 \\
3\end{array}$ & $\begin{array}{r}71 \\
24 \\
5\end{array}$ & $\begin{array}{r}59 \\
32 \\
9\end{array}$ & $\begin{array}{l}35 \\
30 \\
35\end{array}$ & $\begin{array}{l}40 \\
48 \\
12\end{array}$ & $\begin{array}{l}48 \\
24 \\
28\end{array}$ & $\begin{array}{l}36 \\
13 \\
61\end{array}$ & $\begin{array}{r}9 \\
66\end{array}$ \\
\hline IV & $\begin{array}{l}\text { o } \\
\hat{0} \\
\mathrm{~V}\end{array}$ & $\begin{array}{l}75 \\
12 \\
13\end{array}$ & $\begin{array}{l}72 \\
13 \\
15\end{array}$ & $\begin{array}{r}66 \\
4 \\
29\end{array}$ & $\begin{array}{r}75 \\
16 \\
9\end{array}$ & $\begin{array}{l}61 \\
21 \\
18\end{array}$ & $\begin{array}{l}60 \\
25 \\
15\end{array}$ & $\begin{array}{r}72 \\
25 \\
3\end{array}$ & $\begin{array}{l}57 \\
33 \\
10\end{array}$ & $\begin{array}{l}57 \\
33 \\
10\end{array}$ & $\begin{array}{l}57 \\
32 \\
11\end{array}$ & $\begin{array}{l}31 \\
38 \\
31\end{array}$ & $\begin{array}{r}58 \\
36 \\
6\end{array}$ & $\begin{array}{l}42 \\
46 \\
12\end{array}$ & $\begin{array}{l}44 \\
11 \\
45\end{array}$ & $\begin{array}{r}6 \\
68\end{array}$ \\
\hline V & $\frac{q}{0}$ & $\begin{array}{l}72 \\
11 \\
16\end{array}$ & $\begin{array}{r}82 \\
8 \\
10\end{array}$ & $\begin{array}{l}56 \\
16 \\
26\end{array}$ & $\begin{array}{l}64 \\
19 \\
17\end{array}$ & $\begin{array}{r}79 \\
14 \\
7\end{array}$ & $\begin{array}{l}64 \\
18 \\
18\end{array}$ & $\begin{array}{r}58 \\
40 \\
2\end{array}$ & $\begin{array}{r}59 \\
36 \\
5\end{array}$ & $\begin{array}{r}58 \\
34 \\
8\end{array}$ & $\begin{array}{r}50 \\
47 \\
3\end{array}$ & $\begin{array}{l}39 \\
40 \\
21\end{array}$ & $\begin{array}{l}48 \\
36 \\
14\end{array}$ & $\begin{array}{r}36 \\
56 \\
8\end{array}$ & $\begin{array}{l}47 \\
18 \\
35\end{array}$ & $\begin{array}{r}4 \\
76\end{array}$ \\
\hline VI & $\frac{q}{\hat{0}}$ & $\begin{array}{l}65 \\
14 \\
21\end{array}$ & $\begin{array}{r}76 \\
8 \\
16\end{array}$ & - & $\begin{array}{l}58 \\
15 \\
27\end{array}$ & $\begin{array}{l}60 \\
21 \\
19\end{array}$ & $\begin{array}{l}- \\
-\end{array}$ & $\begin{array}{r}58 \\
40 \\
1\end{array}$ & $\begin{array}{r}63 \\
30 \\
7\end{array}$ & $\begin{array}{l}54 \\
33 \\
13\end{array}$ & $\begin{array}{r}49 \\
43 \\
8\end{array}$ & $\begin{array}{l}38 \\
31 \\
31\end{array}$ & $\begin{array}{l}54 \\
34 \\
12\end{array}$ & $\begin{array}{l}44 \\
36 \\
20\end{array}$ & $\begin{array}{l}25 \\
18 \\
57\end{array}$ & - \\
\hline VII & $\begin{array}{l}\text { o } \\
\text { ô } \\
\text { V }\end{array}$ & $\begin{array}{l}- \\
-\end{array}$ & - & - & $\begin{array}{l}72 \\
15 \\
13\end{array}$ & - & - & $\begin{array}{l}- \\
-\end{array}$ & - & - & $\begin{array}{l}- \\
-\end{array}$ & - & 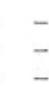 & - & - & \\
\hline
\end{tabular}


TABLE VII.

Actual Numbers of Calanus Copepodid Stage V Taken in Each HaUt.

\begin{tabular}{|c|c|c|c|c|c|c|c|c|}
\hline & 㝴 & $\begin{array}{l}\dot{\Xi} \\
\stackrel{9}{9} \\
\stackrel{9}{9}\end{array}$ & 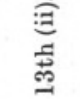 & สี่ & 䓪 & $\dot{\mathrm{I}}$ & 韋 & 总 \\
\hline & $\frac{\overline{5}}{4}$ & $=$ & $=$ & $=$ & $=$ & $\stackrel{\vec{g}}{\vec{z}}$ & $=$ & $\stackrel{9}{\Xi}$ \\
\hline $\mathrm{S}$ & - & - & 6 & 29 & 193 & 6 & - & - \\
\hline II & 47 & 4 & 131 & 239 & 153 & 944 & 185 & 107 \\
\hline III & 249 & 10 & 193 & 597 & 1,696 & 726 & 371 & 1,338 \\
\hline IV & 474 & 267 & 255 & 149 & 556 & 816 & 222 & 1,908 \\
\hline V & 199 & 39 & 106 & 478 & 200 & 747 & 191 & 1,405 \\
\hline VI & 338 & 37 & - & 386 & 234 & - & 55 & 2,938 \\
\hline VII & - & - & - & 250 & - & - & - & - \\
\hline & 薄 & 苛 & हैं & 㫄 & 营 & $\stackrel{\dot{E}}{\dot{H}}$ & ્ㅗํ & \\
\hline & ఏ & $=$ & $\frac{2}{3}$ & $=$ & $=$ & $\sum^{\infty 00}$ & 帝 & \\
\hline S & 5 & - & 177 & - & - & $\left.\begin{array}{r}207,168 \\
10,205\end{array}\right\}$ & 2,592 & \\
\hline II & 85 & - & 1,493 & 208 & 379 & 6,583 & 2,277 & \\
\hline III & 254 & 138 & 1,697 & 175 & 259 & 13,497 & 847 & \\
\hline IV & 487 & 532 & 1,191 & 39 & 123 & 5,769 & 652 & \\
\hline V & 307 & 106 & 584 & 148 & 50 & 3,248 & 404 & \\
\hline VI & 457 & 341 & 713 & 68 & 20 & 1,459 & - & \\
\hline
\end{tabular}

